\title{
Sosyal Bilgiler Öğretmen Adaylarının Estetik Değerine İlişkin Metaforları*
}

\section{Social Studies Prospective Teachers' Metaphoric Perceptions about the Value of Aesthetics**}

\author{
Ayşe SEYHAN, Sorumlu Yazar, Dr. Öğr. Üyesi. \\ Recep Tayyip Erdoğan Üniversitesi, Eğitim Fakültesi, Rize/ Türkiye. \\ ayse.seyhan@erdogan.edu.tr \\ http://orcid.org/0000-0003-1741-4878
}

ISSN: 1303-880X

e-ISSN: 2667-7504

http://ded.dem.org.tr

Makale Türü / Article Type:

Araştırma Makalesi / Research Article

Geliş Tarihi / Received Date: 03.04.2020

Kabul Tarihi / Accepted Date: 10.07. 2020

Yayın Tarihi / Published Date: 25.12.2020

Tr/En: $\operatorname{Tr}$

Intihal / Plagiarism: Bu makale, en az iki hakem tarafindan incelendi ve intihal içermediği teyit edildi. / This article has been reviewed by at least two referees and scanned via a plagiarism software.
Attf/Citatio n : Seyhan, A. (2020). Sosyal bilgiler öğretmen adaylarının estetik değerine ilişkin metaforları. Değerler Ĕgitimi Dergisi, 18 (40), s.115-147.

https://doi.org/10.34234/ded.714332

* XII. Uluslararası Eğitim Araştırmaları Kongresi “21. yy. Öğretmen Eğitimi Politikaları: Kanıt, Araştırma ve Praksis" kongresinde sözlü olarak sunulmuş bildirinin genişletilmiş halidir.

** This study is an expanded version of the paper presented at the The Twelfth International Congress of Educational Research "Teacher Education Policy in the 21st Century: Evidence, Research and Praxis". 
Öz: Bu araştırmanın amacı, sosyal bilgiler öğretmeni adaylarının "Estetik" değerine ilişkin sahip oldukları algıların metaforlar aracılığı ile ortaya çıkarılmasıdır. Araştırma nitel araştırma modeli kapsamında olgubilim deseninde kurgulanmıştır. Çalışma grubunu, Türkiye'de bir üniversitede öğrenim gören 132 öğretmen adayı oluşturmaktadır. Veriler, "Estetik.... gibidir / benzer; çünkü...." şeklinde yazılı form ile toplanmıştır. Elde edilen verilerin değerlendirilmesinde içerik analizi kullanılmıştır. Çalışmada, sosyal bilgiler öğretmen adaylarının "Estetik" değeri için birbirinden farklı olarak 69 geçerli metafor geliştirdiği belirlenmiştir. Belirlenen metaforlar, güzellik (39), uyum (21), etkileyici varlık (18), farklılık (13), mutluluk verici (12), sanat (12), yansitma aracı (8) olmak üzere 7 kavramsal kategoride toplanmıştır. Estetik değeri katılımcılar tarafından en çok doğa (9), evren (7), güzellik (7), sanat (6) ve çiçek (5) metaforları ile ilişkilendirmiştir. Diğer metaforlar bir kez veya iki kez ifade edilmiştir. Geliştirilen metaforların cinsiyete göre dağılımlarına bakıldığında, belirlenen kategorilerin hepsinde, kadın ve erkek katılımcıların hepsinin metafor ürettikleri görülmektedir. Geliştirilen metafor sayısı açısından "Yansıtma aracı olarak estetik" kategorisinde kadın ve erkek katılımcılar eşit sayıda metafor üretmiştir. Diğer kategorilerde kadın katılımcıların daha fazla metafor geliştirdiği anlaşılmaktadır.

Anahtar Kelimeler: Sosyal bilgiler, Estetik, Değer, Sosyal bilgiler öğretmen aday1, Metafor.

$\&$

Abstract: The purpose of this study is to reveal the perceptions of the prospective social studies teachers regarding the "Aesthetic" value through metaphors. The research was designed in phenomenological pattern within the scope of qualitative research model. The Working group consists of 120 prospective social studies teachers studying at a university in Turkey. Data collected with a written form as "Aesthetic...... as/similar; Because......." which evaluated with content analysis. In the study it was determined that the prospective teachers of social studies developed 69 valid metaphors different from each other for the concept of "Aesthetics". metaphors were divided in in 7 conceptual categories: beauty (39), harmony (21), impressive existence (18), difference (13), pleasing (12), art (12), mirroring tool (8). The aesthetic value was mostly associated with the metaphors as nature (9), universe (7), beauty (7), art (6) and flower (5) by participants. Other metaphors were expressed once or twice. Looking at the developed metaphors' distribution according to gender, in all determined categories all male and female participants have produced metaphor. In terms of the 
number of metaphors developed, male and female teacher candidates produced equal numbers of metaphors under "Aesthetic as mirroring tool" category. Yet, it was found that female students develop more metaphors in other categories.

Keywords: Social studies, Aesthetics, Value, Social science prospective teacher, Metaphor.

(The Extended Abstract is at the end of the article)

\section{Giriş}

Toplumlar kendi değerlerini eğitim öğretim yoluyla nesillerine aktarmaktadırlar (Kıncal, 2007). Çok disiplinli yapısı ve konularının toplumla olan bağlantısı sosyal bilgiler dersinin değer öğretimindeki önemini artırmaktadır (Kan, 2010). Değer "bir şeyin önemini belirlemeye yarayan soyut ölçü, bir şeyin geldiği karş1lık, kıymet; bir ulusun sahip olduğu sosyal, kültürel, ekonomik ve bilimsel değerleri kapsayan maddi ve manevi ögelerin bütünü” olarak tanımlanmaktadır (Türk Dil Kurumu [TDK], 2019). Estetik, sosyal bilgiler dersinde öğrencilere kazandırılması amaçlanan değerlerden biridir. Estetik sözcüğü Grekçe "Duygu, duyarlı algilama" anlamına gelen "Aisthanesthai” teriminden gelmekte ve güzellik bilimi anlamında kullanılmaktadır (Uhrmacher, 2009; Artut, 2013). Estetik, "sanatsal yaratının genel yasalarıyla sanatta ve hayatta güzelliğin kuramsal bilimi, güzel duyu"dur (TDK, 2019). Diğer bir tanımda estetik; güzeli konu eden, iyi, çirkin, hoş, yüce, trajik gibi güzellikle yakından ilişkili, doğal ya da insan ürünü olan nesneleri, değerleri, tavırları, haz ve tatları analiz eden bir felsefe dalı olarak belirtilmektedir (Cevizci, 1999). Estetik, "sanatın kökeni, doğası, güzellik değerinin tanımlanması ve bu değerlere karşı insanların tutum ve davranışlarını inceleyen, sanatı ve sanat yapıtlarını değerlendirmeye yönelik bir düşünce biçimi”, "güzelin doğası, anlamı, niteliğinin çözümlenmesi, insanın günlük yaşamındaki etkinlikleri sonucunda oluşan ve güzel olarak nitelendirilen değerlerin bilimi"dir (Artut, 2013).

Cevizci'ye (1999) göre estetik; estetik suje, estetik obje, estetik yaşantı, estetik hayal gücü, estetik duygu ve haz, estetik değer olmak üzere altı ögeyi içermektedir. Bengisu'ya göre (2011) estetik; estetik suje, estetik obje, estetik değer ya da estetik yargı bileşenlerinden oluşmaktadır. Nesnenin güzellik değerini algılayan, ondan etkilenen, belli bir güzellik duygusuna, estetik beğeniye sahip olan bilinçli insan varlığına "estetik suje", bir güzelliğe ve estetik bir beğeniye sahip olan insanın kendisine yöneldiği şeye "estetik obje" denilmektedir 
(Cevizci, 1999). Estetik haz ise kişiye mutluluk veren, kişiliğinde değişiklik oluşturan, sanat yapıtlarından hoşlanmadır (Tunalı, 2004). Güzelliği hissetmeye ve bulmaya çalışmak ise estetik anlayış olarak belirtilmektedir. Bireylerin estetik anlayış kazanmaları güzelliği anlama ve içeriğin özüne inme yeterliliğine sahip olmalarına bağlıdır (Özalp, 2016). Bireylerin estetik anlayış ve estetik değer kazanmaları, çevreleri ile ilişkileri ve deneyimlerine göre farklılaşmaktadır (Wong, 2007). Çünkü bireylerin estetik anlayışlarını çevre, eğitim, kültürel birikim, toplumsal kazanımlar, iyi ve kötü yaşantılar, değerlendirici veya normatif inançlar etkilemektedir (Montague, 1979; Artut, 2013). Ayrıca, sanat eserinin içinde bulunduğu bireysel, toplumsal birikimler ile eseri oluşturan sanatsal elemanlar arasındaki uyum, eserin verdiği mesaj, izleyene karşı hissettirdiği duygu ve değerlendirmedeki objektiflik de eserin değerlendirilmesinde etkili olmaktadır. Eserin değerini biçme, eserle sözü edilen özellikleri bütünleştirme sürecinde o eseri güzel bulduğunu farklı şekillerde ifade etmektir (Özalp, 2016). Bireylerde estetik alg1 ve anlayışın gelişmesiyle nesneye verilecek estetik değerin de sınırları çizilmektedir (Artut, 2013; Özalp, 2016). Sanat yapıtı ile ilişki kuran bireyin ondan haz duyması, ruhsal dinginlik ve mutluluk yaşaması neticesinde sanat yapıtına yönelik kullandığı güzel, hoş ve ilginç gibi ifadeler estetik yargıdır. Bir nesneyi algılamak, kavramak ve ondan haz duymak için ona karşı tavır almak gerekir. Estetik tavır bireyin beğeni düzeyinin belirleyicisidir (Artut, 2013). Estetik değer ise sanatçılar tarafından oluşturulan heykel, tablo, bina vb. eserlerde bulunan ve onları sanat eseri haline getiren özelliklerdir.

Sanatın tüm alanlarında üretilen ve estetik değeri olan bir nesne sanat eseri olabilir. Bir sanat eserinin estetik değer kazanabilmesi için hiçbir çıkar düşünmeden o eserden haz duyan ve onu takdir eden bireylerin varlığı gereklidir (Ergün, 2010). Estetiğe önem vermeyen veya estetik değerini dışlayan eğitimlerin problemli olduğu belirtilmektedir (Wong, 2007). Estetik eğitimi, deneyimler yoluyla güzeli algılama ve bundan haz duyma konusunda kişiye disiplin kazandırmadır. Estetik eğitimi zariflik, asalet, kibarlık kazandırmanın yanında, kişinin çevresindeki olaylara karşı duyarlı olmasını da sağlayan bir eğitimdir (Özalp, 2016). Estetik eğitimi, bireylerin bütünleşik yetkinlik gelişimini kolaylaştırmak için psikomotor, algısal, duyuşsal, bilişsel, ahlaki ve estetik öğrenme potansiyelini içeren faaliyetlerdir (Brainerd ve Marshall 1976). Estetik eğitimi kişide önceden var olan birikim ve çevresel etkenlerin dışında zihnin bakış açısını eğiten, estetik tavrı bilinçli hale getiren bir niteliğe sahiptir. Estetik eğitimi, öğrencileri sanat hakkında sistematik sorular sormaya yöneltme, sanatı değerlendirme, sanata değer yargısı yönünden tepki verme ve takdir etmeyi sağlamadır (Dobbs, 
1998:50, akt; Özalp, 2016). Yaşanılan dönem, kültür, eğitim farklılıkları sanat yapıtlarından estetik anlayışı ve eserden haz duymayı farklılaştırmaktadır. Bu yüzden estetik eğitiminde sosyal, kültürel ve kişisel değerler ile yaşanılan dönemin koşullarının dikkate alınmasını gerektirmektedir (Gökay, 2005). Sanat eserleri varlıklarını ve değerlerini ait olduğu kültür yapısından aldıkları için bir eser değerlendirilirken o eserin geliştirildiği kültürle temas kurmak gerekir (Bengisu, 2011).

Estetik değerinin bireylere ve topluma birçok açıdan faydası olduğu belirtilmektedir. Estetik, çocuklarda beğeni duygusunu geliştirerek onların dünyaya ve olaylara bakışlarında yeni değerler kazanmalarına yardımcı olur (Mazman Budak, 2012). Estetik değeri kazanma sürecinde öğrenciler nesnelerin ayrıntıları üzerinde çalışarak estetik bakış açısı ve hayat disiplini geliştirir. Estetik değeri bireylerin doğal ve yapay çevredeki ayrıntıları fark etmelerini sağlar. Bireylerin tasarım yeterliliğini artırır. Farklı anlatımları yorumlayabilme becerilerini geliştirir. Böylece birey yaratıcı gücünü estetik bir düzeyde anlatabilir. Estetik eğitim ile bireysel birikim ve buna bağlı olarak bireysel farkındalık oluştuğundan bireyin inancı ve ahlaki değerleri gelişir. Yetenekleri, gittikçe gelişen birey karmaşık nesnelerin özüne inebilir. Birey estetik hazza ulaşarak sanat algısı geliştirir (Karaahmet Balcı 2015; Özalp, 2016). Estetik eğitimi çocukların kişisel becerileri, düşünme yetileri ve duyu algılarını geliştirerek onların gözlemlerine ve algılarına dayalı olarak kendilerini dışa vurmalarına ve ifade edebilmelerine olanak tanır (Gültekin, 2013). Estetik değeri öz denetim kazandırarak bireyin özenli, dikkatli ve disiplinli olmasını sağlar. Birey güzel olana karşı farkındalık geliştirerek güzeli oluşturma çabası içerisine girer. Estetik değeri bireylere sanatsal bir bakış açısı kazandırarak, ayırt etme, fark etme, duyarlı olma, hayattan zevk alma, haz duyma, güzel konuşma, güzel yazma, nezaket sahibi olma gibi kişisel ve sosyal becerilerini geliştirir. Bireylerde sorumluluk duygusunu geliştirerek onlara maddi ve manevi kültür estetik değeri kazandırır. Böylece bireyler kültürel mirasa, tarihi ve doğal çevreye karşı duyarlı olur (Uludağ ve Odac1, 2002; Gültekin, 2011; Artut, 2013; Karaahmet Balc1 2015; Özalp, 2016; Özbal, Aydoğan, 2017).

Estetik alg1 düzeyi yüksek bireyler gördüklerini anlamlandırma da olduğu kadar kendi üretecekleri görsellerde de bu estetik kaygıyı taşıyarak daha başarılı üretim süreçleri geçirebilir (Özalp, 2016). Estetik değeri kişinin dikkatini artırarak, ilgisini uyandırarak öğrenmekten zevk almasını sağlar. Birey estetik deneyim yaşayarak insanlar ve dünya ile temas kurarak onların niteliklerini kavrar. Estetik 
değeri kişiye, bir olay veya olguyu geçmiş, bugün ve gelecek bağlamında değerlendirme yetisi kazandırır. Kişinin geçmişin nasıl inşa edildiğini anlamasına ve insanlığın öğrenmeyle nasıl geliştiğini görmesine firsat verir (Uhrmacher, 2009). Estetik deneyim kişilere duyusal bir tecrübe kazandırarak onların estetik seçim ve değerlendirmelerinde bu tecrübelerden faydalanmalarını sağlar (Eaton ve Moore, 2002). Birey sadece sanatta estetik deneyim ve sanatsal uygulama için beceriler geliştirmekle kalmaz, yaratıcı problem çözme becerilerini geliştirerek diğer alanlardaki öğrenmelerini de büyük ölçüde artırır (Brainerd ve Marshall, 1976). Estetik deneyim, birden fazla bilgiyi tanıma yolunu birleştirir. Bireylerin başka türlü göz ardı edebilecekleri bağlantıları algılamalarını sağlar. Bireylerin hayal gücü ve düşünmelerini eylemleri ile uyumlaştırır (Kerdeman, 2005).

Estetik değeri duyularla gelişir. Duyular ise akıl, merak ve ilgiyle harekete geçmektedir. Estetik deneyimler bilimi tanıma ve onu çevremizdeki dünyaya uygulama şeklimizdir. Birey, nesneyi duyusal deneyim yoluyla algılayarak, nesne ile zengin bağlantılar kurar. Nesne ile karşılıklı etkileşime geçerek estetik bir deneyim yaşar (Uhrmacher, 2009). Estetik yargı için görsel olarak algılanan nesnelerde algılanan verinin özümsenmesi ve bu verilerin akılda düzenlenmesi gerekir. Estetik değeri belirleme, sanat eserini anlama ve eleştirmeyi gerektirir. Bireylerin estetik değer belirlemeleri görsel algılarının geliştirilmesine bağlıdır (Bolton, 1973). Erken çocukluk döneminde duyusal alg1, yaratıcılık ve estetiğin geliştirilmesi gerekliliği eğitim öğretimde aktif öğrenme süreçlerini kullanmay1 ve duyarlı öğrenme ortamı oluşturmayı zorunlu kılmaktadır. Bu yüzden öğretmenler çocukların estetik gelişimleri için gerekli ortamı sağlayarak onların öğrenmelerini kolaylaştırmalıdır. Öğretmenler hizmet öncesi veya hizmet içi eğitimler ile estetik değerini geliştirebilecekleri duyarlı bir öğrenme ortamı oluşturma eğitimi almalıdırlar (Brainerd ve Marshall, 1976). Bir öğretmen estetik öğrenme deneyimleri için öğrencilere firsat yaratmalı veya onların firsatlarını arttırmalıdır. Estetik deneyim yaşatacak tüm unsurları dikkatle değerlendirmelidir. Aktif katılım, duyusal deneyim, bağlantılar, hayal gücü, alg1 ve risk alma, estetik deneyimi teşvik eden unsurlardır. Öğretmenler sınıf etkinliklerini sanatsal uygulamalarla öğrencilerin estetik deneyim yaşayacakları şekilde geliştirmeli ve zenginleştirmelidir (Uhrmacher, 2009).

Duygu, değer ve tutumlar hem zihinsel hem de bedensel aktivitelerle geliştirilebilir. Bu yüzden derslerde öğrencilerin sanat, müzik, dans ve drama gibi çalışmalar yapabileceği etkinlikler seçilmelidir (Miles, 1962). Öğretmenler estetik deneyim için sınıf içi ve sınıf dışı etkinlikler ile öğrencilere entelektüel 
deneyimler yaşatmalıdır (Biscotte, 2015). Olumlu estetik yarg1, gözlem ile bir hazzı ifade etmenin dışında süreklilik ve değişimi ifade etmek için de kullanı1ır. Estetik eğitimde öğretmen esere yönelik doğru sorular sorarak öğrencilerin doğru ilerlemesini sağlamalı ve onları olumlu estetik deneyime doğru yönlendirmelidir (Jakobson ve Wickman, 2008).

Müze eğitimi estetik değerinin geliştirilmesinde önemli yer tutmaktadır. Ancak müzeler gezilerek eserlerin öğrencilere sadece gösterilmesiyle estetik anlayışın geliştirilemediği belirtilmektedir (Lachapelle ve diğerleri, 2003). Eaton ve Moore, (2002) okullarda ve müzelerde gezerek sadece bir sanat eserinin varl1ğını bilme ve görmenin yeterli olmadığını, estetik değerinin ancak sanat eserinin estetik bir etkiye sahip olan her türlü bilgisinin değerlendirmesi ile estetik deneyim ve tecrübe yaşatılarak kazandırılabileceğini belirtmektedir. Eserin değerlendirilmesinde, eserin kim tarafından nasıl ve kimin için yapıldığı, eserin mesajı, tarzı, içinde bulunduğu kültüre ilişkin bilgiler gibi her türlü gerçeğin sorgulanması gerekmektedir. Ayrıca esere yönelik duyguları etkileyen sorular yönlendirilmelidir. Eserin öğrencilere ne hissettirdiği ve öğrencinin neden böyle hissettiğinin sorularak eser hakkında öğrencilerin görüşlerinin alınması gerektiği belirtilmektedir. Eserin çiziminin yapılmasının görsel algıyı geliştireceği ve eserin algılanma düzeyini artıracağı ifade edilmektedir. Bu şekilde teorik öğrenme ile deneyimsel öğrenmenin birleştirilmesi önerilmektedir (Lachapelle ve diğerleri, 2003). Johnson'a göre (1998) bir eserin estetik değerinin üç düzeyde incelenmesi gerekir. Bunlar;

1. Duyusal düzey: eserin renkleri, çizgileri, formları, dokuları ve bu ögeler arasındaki ilişkidir.

2. Deneyimsel derinlik: geçmiş deneyimlerin (görüntü, fikir vb) unsurlarını, eserle ilgili olarak algıladıklarımızla birleştirilmesidir.

3. Sanat eserinin toplam ifadesi: estetik bağlamda eserde bulunması gereken özelliklerdir.

Estetik eğitimde sanat eserine odaklanılarak yukarda verilen üç düzeyde yansıtıcı yargıda bulanabilecek sorulardan oluşan sanat eleştirisi çalışması yapılabilir. Sanat eleştiri çalışmasında; sanat eserinin yapısı, eserin oluşturan unsurlar, eserin doğduğu toplumun özellikleri, eserin kimliği, eserin betimlenmesi (şekil, renk, doku, figür, yapıldığı teknik vb.) eserin çözümlenmesi, yorumlanması ile eser hakkında estetik yargıya varacak inceleme, araştırma ve sorgulama bölümlerinin yer alması gerekmektedir (Milli Eğitim Bakanlığı [MEB], 2016). 2018 Sosyal Bilgiler Öğretim Programı'nın amaçlarında ilkokulu tamamlayan öğren- 
cilerin estetik duyarlılığını kazanmış olmaları beklenmektedir. Programda estetik değeri kazanımları itibariyle birçok öğrenme alanı ile ilgili olmakla birlikte "Kültür ve Miras" öğrenme alanındaki kazanımlarla daha çok ilişkilendirildiği görülmektedir (MEB, 2018).

Sosyal bilgiler öğretiminde önemli yere sahip olması bakımından estetik değeri hakkında öğretmen adaylarının algıları da önem taşımaktadır. Bu çalışmada sosyal bilgiler öğretmen adaylarının estetik algılarının metaforlar aracılı̆̆ ile ortaya çıkarılması amaçlanmıştır. Metafor kavramı Ertürk'e göre (2017) kavramsal bir ifadeyi başka bir kavramsal ifadeye benzetmektir. Çalışkan'a göre (2009) metafor, bilgiyi kavramada alternatif yorumlar getiren, kimi zaman kendine has bir gerçeklik, bilgi üreten bir sistemdir. Saban'a göre (2008) metafor iki nesne veya kavramı birbirine bağlayan dilsel bir araçtır. Metaforlar bir bireyin zihninin belli bir kavrayış biçiminden başka bir anlayış biçimine hareket etmesini sağlar. Metaforlar iki şey arasında karşılaştırma yapmak, iki şey arasındaki benzerliklere dikkat çekmek amacıyla veya bir şeyi başka bir şeyin yerine koyarak açıklamak için insanlara kolaylık sağlarlar. Arslan ve Bayrakçı'ya göre (2006) metaforlar bireylerin kendi dünyalarını anlamalarına ve yapılandırmalarına yönelik güçlü bir zihinsel haritalama ve modelleme sistemi olarak tanımlanmaktadır.

Alan yazında sosyal bilgiler öğretmenlerinin ve öğretmen adaylarının farklı konulara ilişkin görüşlerinin metaforlar aracılığıyla alındığı birçok araştırma tespit edilmektedir. Meral, Küçük ve Gedik (2016) sosyal bilgiler öğretmen adaylarının çevre kavramına ilişkin sahip oldukları metaforları ortaya çıkarmak için yaptıkları çalışmada, katılımcıların çoğunlukla çevre kavramına "insan" $(\% 11,60)$, "ev" $(\% 7,73)$, "aile" $(\% 6,62)$, "anne" $(\% 5,52)$, “çocuk" $(\% 4,97)$ metaforlarını ürettiklerini belirtmişlerdir. Akhan, Kılıçoğlu ve Gedik (2014) sosyal bilgiler öğretmenliği birinci sınıf öğretmen adaylarının sosyal bilgiler ve sosyal bilimlere yönelik algılarını ortaya koymaya yönelik araştırmalarında, öğretmen adaylarının tarih, coğrafya, sosyoloji, arkeoloji, sanat tarihi disiplinleri ile ilgili genellikle olumlu yönde metafor geliştirdikleri tespit etmişlerdir. Tuna Er ve Mazman Budak (2013) çalışmalarında sosyal bilgiler öğretmen adaylarının "tarih" kavramıla ilgili 62 farklı metafor kullandıklarını ve bu metaforların hayatın içinden kavramlardan geliştirildiğini belirtmişlerdir. Kullanılan metaforların zenginliği ve çeşitliliğini öğretmen adaylarının tarih algılarının kuvvetli ve gelişmiş olmasından kaynaklandığını ifade etmişlerdir. Kaya (2014) araştırmasında sosyal bilgiler öğretmen adaylarının çevre sorunlarına yönelik 5 kavramsal kategoride 48 geçerli metafor ürettiklerini belirterek öğretmen adaylarının çev- 
re sorunlarına yönelik farkındalıklarının yüksek olduğunu belirtmiştir. Koçoğlu (2014) sosyal bilgiler öğretmenlerinin sosyal bilgiler kavramına ilişkin imgesel algılarını tespit etmeye yönelik çalışmasında, öğretmenlerin zihinsel imgelerinin çeşitlilik gösterdiğini ve sosyal bilgilerin bütün özelliklerini içerdiğini ortaya koymuştur. Sosyal bilgiler öğretiminde bağımsızlık değeri hakkında sosyal bilgiler öğretmen adaylarının algılarını inceleyen Kalın Ulu ve Koçoğlu (2017) çalışmalarında, öğretmen adaylarının bağımsızlık kavramını en çok özgür olma durumu olarak nitelendirdiklerini ve etkili yurttaş yetiştirmek için bağımsızlık değerini doğru algıladıklarını belirtmişlerdir. Demirkaya ve Çal'a göre (2018) sosyal bilgiler öğretmeni adayları dürüstlük değerine; doğa, nesne, soyut ve diğer teması olmak üzere 88 farklı metafor geliştirmiştir. Akhan (2013) sosyal bilgiler öğretmen adaylarının sanat algılarını ve sosyal bilgiler dersi kapsamındaki sanat konuları ve öğretimi ile ilgili görüşlerini incelediği araştırmasında, öğretmen adaylarının sanat konularının öğretiminin gerekli olduğuna inandıklarını ama bu konuda kendilerini yetersiz gördüklerini ifade etmiştir. Kılcan ve Akbaba (2014) sekizinci sınıf öğrencilerinin büyük bir çoğunluğunun estetiği "insana hoş gelen, göze hitap eden hoş, sorunsuz ve kusursuz bir görüntü” şeklinde algıladıklarını ortaya koymuşlardır.

Sosyal bilgiler öğretmeni adaylarının "Estetik" değerine ilişkin algılarının metaforlar aracılığı ile ortaya çıkarılmasının amaçlandığı bu çalışmada aşağıdaki sorulara cevap aranmıştır:

1. Öğretmen adaylarının estetik değerine ilişkin sahip oldukları metaforlar nelerdir?

2. Estetik değerine ilişkin metaforlar ortak özellikleri bakımından hangi kavramsal kategoriler altında toplanabilir?

3. Öğretmen adaylarının cinsiyetleri bakımından kavramsal kategoriler farklılık göstermekte midir?

\section{Yöntem}

\section{Araştırma Modeli}

$\mathrm{Bu}$ çalışma, nitel bir araştırmadır. Veri toplama ve yorumlama sürecinde nitel araştırma yöntemleri desenlerinden biri olan olgu bilim deseni kullanılmıştır. Olgu bilim (fenomenolojik) deseni, günlük yaşamda farkında olduğumuz ama derinlemesine ve ayrıntılı bir anlayışa sahip olmadığımız olgulara odaklanmaktadır (Yıldırım ve Şimşek, 2016). Fenomonoloji günlük deneyimlerimizin anla- 
mı ve doğası hakkında derinlemesine anlayışın kazanılmasını amaçlamaktadır (Patton, 2018).

\section{Çalışma Grubu}

Çalışma grubu 2018-2019 Akademik yılı güz yarıyılında Recep Tayyip Erdoğan Üniversitesi Eğitim Fakültesi Sosyal Bilgiler Öğretmenliği ABD'de öğrenim gören 79 kadın, 53 erkek olmak üzere toplamda 132 öğretmen adayından oluşmaktadır. Araştırmaya katılan öğretmen adaylarının belirlenmesinde seçkisiz olmayan örnekleme yöntemlerinden kolay ulaşılabilir durum örneklemesi kullanılmıştır. Yapılan analizlerde 75 kadın (\%60), 48 (\%39) erkek olmak üzere 123 öğretmen adayının formu geçerli olurken 4 kadın, 5 erkek olmak üzere toplam 9 öğretmen adayının formu geçersiz sayılarak kullanılmamıştır. Öğretmen adaylarının 32'si birinci sınıf, 31'i ikinci sınıf, 25'i üçüncü sınıf, 35'i de dördüncü sınıf düzeyinde öğrenim görmektedir. Katılımcıların demografik özellikleri Tablo 1'de verilmiştir.

\begin{tabular}{lllllll}
\hline \multicolumn{7}{l}{ Tablo 1: Çalışma Grubunun Demografik Özellikleri } \\
\hline Cinsiyet & 1. Sınıf & 2. Sınıf & 3. Sınıf & 4. Sınıf & Toplam & \% \\
\hline Kadın & 21 & 15 & 15 & 24 & 75 & 60,97 \\
\hline Erkek & 11 & 16 & 10 & 11 & 48 & 39,02 \\
\hline Toplam & $\mathbf{3 2}$ & $\mathbf{3 1}$ & $\mathbf{2 5}$ & $\mathbf{3 5}$ & $\mathbf{1 2 3}$ & 100 \\
\hline
\end{tabular}

\section{Veri Toplama Araci}

Veri toplama aracı geliştirilirken, farklı kavram ve konularda bireylerin alg1 veya görüşlerini tespit etmeye yönelik yapılan araştırmalar (Saban, 2008; Akhan, K1lıçoğlu ve Gedik, 2014; Çelikkaya ve Yakar, 2015) incelendi. Bu araştırmalarda "gibi" edatı genellikle metaforun konusu ve metaforun kaynağ arasındaki ilişkiyi daha açık bir biçimde ortaya koymak, "çünkü" bağlacının ise metaforların oluşturulma sebebinin açıklanmasının istenildiği durumlarda tercih edildiği anlaşıldı. İlgili araştırmalara dayanarak, araştırmaya katılan öğretmen adaylarının estetik kavramına ilişkin sahip oldukları algıları ortaya çıarmak için hazırlanan form iki bölümden oluşmaktadır. İlk bölümünde katılımcıların kişisel bilgilerine yönelik sorular, ikinci bölümünde ise "Estetik.... gibidir/benzer; Çünkü......" cümlesi yer almıştır. Öğretmen adayları tarafından doldurulan bu form birer belge ve doküman olarak bu araştırmanın temel veri kaynağını oluşturmuştur. 


\section{Verilerin Analizi}

Araştırmanın verilerinin analizinde ve değerlendirilmesinde içerik analizi tekniği kullanılmıştır. İçerik analizi ile toplanan verileri açıklayabilecek kavramlara ve ilişkilere ulaşılmak amaçlanmaktadır. İçerik analizinde birbirine benzeyen veriler belirli kavramlar ve temalar çerçevesinde bir araya getirilerek okuyucunun anlayacağı şekilde düzenlenip yorumlanmaktadır (Yıldırım ve Şimşek, 2016). Bu çerçevede öğretmen adayları tarafından geliştirilen metaforlar, kodlama yoluyla verilerin altında yatan kavramları ve bu kavramlar arasındaki ilişkileri ortaya çıkaran tümevarımcı analiz yöntemiyle analiz edilmiştir. Metaforların analizi Saban (2008), Deniş Çeliker ve Akar'ın (2015) çalışmalarındaki basamaklar örnek alınarak yapılmıştır:

\section{Adlandirma aşaması}

$\mathrm{Bu}$ aşamada öncelikle öğretmen adaylarının "Estetik" kavramına yönelik üretmiş oldukları metaforların geçici bir alfabetik listesi yapılmıştır. Listeleme işlemi tamamlandıktan sonra öğretmen adaylarının anlamlı metaforlar ve bunları açıklayan anlamlı cümleler kurup kuramadıklarına bakılmıştır. Bu aşamada kategorileştirme aşamasına zemin oluşturmak için üretilen metaforlara ilişkin kodlar yazılmıştır.

\section{Eleme aşaması}

Eleme aşamasında öğretmen adayları tarafından üretilen metaforlardan sadece tanımlama yapılan, herhangi bir metafor kaynağı belirtmeyen, belli bir metafordan söz edilmesine rağmen metafor için herhangi bir gerekçe sunulmayan veriler ile birden fazla kategoriye ait özellik içeren ve estetik değerinin anlaşılmasına katkı sağlamayan veriler (n: 9) geçersiz sayılarak kapsam dışı bırakılmıştır.

\section{Kategori geliştirme aşaması}

Öğretmen adayları tarafından üretilen metaforların "Estetik” kavramına ilişkin sahip oldukları ortak özellikler bakımından incelenmiş ve bu metaforların nasıl kavramsallaştırıldığına bakılmıştır. Bu doğrultuda adlandırma aşamasında metaforlara verilen kodlar dikkate alınarak, benzer temaları içeren metaforlar aynı kategoriye dahil edilmiştir. Ayrıca kategorilerin nasıl oluşturulduğuna 1şık tutması açısından öğretmen adaylarının ifadelerine yer verilmiştir. Öğretmen adaylarının doğrudan ifadeleri yazılırken gerçek isimleri yerine kodlar kulla- 
nılmıştır. Örneğin birinci sırada kadın öğretmen adayına " $\mathrm{K}, 1$ " kodu verilmiştir. Bu aşamada öğretmen adayları tarafindan üretilen her bir metafor "Estetik" kavramına ilişkin sahip oldukları bakış açısına göre belli bir tema ile ilişkilendirilerek 7 farklı kategori oluşturulmuştur.

\section{Geçerlik ve güvenirliği sağlama aşaması}

Araştırma sonuçlarının geçerliliğini sağlamada iki önemli süreç gerçekleştirilmektedir (Yıldırım ve Şimşek, 2016). Bu araştırmada veri analiz süreci detaylı bir şekilde açıklanmıştır. Araştırmada elde edilen 69 metaforun her biri için onu en iyi temsil ettiği varsayılan bir örnek metafor imgesi derlenmiş ve bu metafor imgelerinin tümüne bulgular kısmında yer verilmiştir. Bulguların işlenmesinde ve yorumlanmasında öğretmen adaylarının kendi el yazıları ile yazdıkları metafor imgeleri, temel veri kaynağı olarak kullanılarak her kavramsal kategoriyi oluşturan alt özelliklerin her biri en az bir öğrenci metafor imgesiyle (yani doğrudan alıntılarla) desteklenmiştir. Ayrıca 7 kategori altında toplanan metafor imgelerinin kavramsal kategorileri temsil edip etmediğini kontrol etmek amacıyla sosyal bilgiler eğitimi alanında iki uzmanın görüşüne başvurulmuştur. Bu amaçla uzmanlara metaforları ve kategorileri içeren listeler verilerek bu metaforları kategorilerle ilişkilendirmeleri istenmiştir. Daha sonra bu eşleştirmeler araştırmacının kendi kategori eşleştirmeleriyle karşıllaştırılmıştır. Karşılaştırma ile görüş birliği ve görüş ayrılığı sayıları tespit edilip, Miles ve Huberman'ın (2016) güvenirlik formülü (Güvenirlik: görüş birliği / görüş birliği + görüş ayrılığ x 100) kullanılarak \%92 oranında uzlaşma sağlanmıştır. Miles ve Huberman (2016) güvenirlik sonucunun \%70'in üzerinde çıkmasının araştırmanın güvenirliği için geçerli bir oran olduğunu belirtmektedir. Saban'a göre (2008) veriler üzerinde uzman ve araştırmacı değerlendirmeleri arasındaki uyumun $\% 90$ ve üzeri olması istenilen güvenirliğin sağlanması için yeterli görülmektedir.

\section{Frekansların hesaplanması ve verilerin yorumlanması}

Toplamda 69 geçerli metaforun belirlenmesinden ve bu metaforların oluşturduğu 7 kavramsal kategorinin geliştirilmesinden sonra bütün veriler bilgisayar ortamında Microsoft Excel programına aktarılmıştır. Bu aşamada oluşturulan kategoriler tablolaştııılmış ve öğretmen adaylarının bu metaforları kullanma sıklıklarının frekans ve yüzdeleri hesaplanmıştır. Bu şekilde elde edilen veriler yorumlanmıştır. 


\section{Bulgular}

Bu bölümde araştırma sonucunda ulaşılan bulgular sunulmuştur. Çalışmanın ilk sorusu sosyal bilgiler öğretmen adaylarının estetik değerine ilişkin ürettikleri metaforların neler olduğuydu. Katılımcıların sahip oldukları metaforlar nelerdir? Tablo 2'de alfabetik sıraya göre gösterilmiştir.

\begin{tabular}{|c|c|c|c|c|c|c|c|}
\hline Altın oran 1 & 1 & Evren & 7 & Kadın & 1 & $\mathrm{Su}$ & 3 \\
\hline Anne & 1 & Fayda & 1 & Matematik & 1 & Şiir & 1 \\
\hline Aşk & 2 & Geometrik şekil & 1 & Messi'nin futbolu & 1 & Tablo & 5 \\
\hline Ay parças1 & 1 & Gökkuşağ1 & 1 & Mevsim & 1 & Takım tutmak & 1 \\
\hline Ayna & 2 & Gökyüzü & 1 & Modifiye & 1 & Tarihi yap1 & 1 \\
\hline Bilgi & 1 & Göz & 3 & Mükemmellik & 1 & Tavus kuşu & 2 \\
\hline Bina & 1 & Gün batımı & 1 & Müzik & 1 & Vücut & 1 \\
\hline Bütün & 1 & Güneş & 3 & Okyanus & 2 & Yağmurda islanmak & 1 \\
\hline Çiçek & 5 & $\begin{array}{l}\text { Güneşin batışını } \\
\text { izlemek }\end{array}$ & 1 & Operasyon & 2 & Yapaylık & 1 \\
\hline $\begin{array}{l}\text { Çöldeki } \\
\text { papatya }\end{array}$ & 1 & Güneşin doğuşu & 1 & Orant1 & 1 & Yap1 & 1 \\
\hline Değişkenlik & 1 & Güzel bir kız & 1 & Pirlanta & 2 & Yaratılmış varlık & 1 \\
\hline Deniz & 2 & Güzellik & 7 & Resim & 3 & Yaşam & 2 \\
\hline Dış görünüş & 1 & Hayal gücü & 1 & Sanat & 6 & Yaşam biçimi & 1 \\
\hline Doğa & 9 & Heykel & 2 & Sarı kırmızı & 1 & Yemek & 1 \\
\hline Dokunma & 1 & Hoş koku & 1 & Sarmaşık & 1 & Yeni doğan bebek & 1 \\
\hline Duygu & 2 & İklim & 1 & Selimiye Camii & 1 & & \\
\hline Dünya & 1 & İnci & 1 & Sihirli değnek & 1 & & \\
\hline \multirow[t]{2}{*}{ Erguvan } & 1 & İnsan & 3 & Siyasi görüş & 1 & & \\
\hline & & & & & & Toplam & 69 \\
\hline
\end{tabular}

Tablo 2'ye göre 123 öğretmen aday1 "Estetik” kavramı için toplamda birbirinden farklı olarak 69 metafor geliştirmiştir. Bu metaforlardan 48 tanesi yalnızca bir katılımcı tarafından üretilmiştir.

Çalışmanın ikinci sorusu estetik değerine ilişkin metaforlar ortak özellikleri bakımından hangi kavramsal kategoriler altında toplanabilir. Katılımcıların estetik değerine ilişkin sahip oldukları metaforlara ait kategoriler Tablo 3'te verilmiştir. Ayrıca bu kategorilere ilişkin yanıtlardan doğrudan alıntı yapılmıştır.

Tablo 3: Estetik Değerine İlişkin Metaforların Kategorik Dağıllımı

\begin{tabular}{|c|c|c|c|}
\hline Kategoriler & Metaforlar & Frekans & $\%$ \\
\hline $\begin{array}{l}\text { Güzellik temsili } \\
\text { olarak estetik }\end{array}$ & $\begin{array}{l}\text { Güzellik (7), doğa (6), su (3), tavus kuşu (2), pirlanta (2), } \\
\text { yaşam (2), çiçek (2), operasyon (2), yapaylık (2), vücut } \\
\text { (1), okyanus (1), inci (1), yaratılmış varlık (1), yapı (1), } \\
\text { mükemmellik (1), evren (1), bilgi (1), tablo (1), diş görünüş, } \\
\text { (1), sanat (1) }\end{array}$ & 39 & 31,70 \\
\hline
\end{tabular}




\begin{tabular}{|c|c|c|c|}
\hline $\begin{array}{l}\text { Uyum olarak } \\
\text { estetik }\end{array}$ & $\begin{array}{l}\text { Doğa (3), güneş (2), deniz (2), sarmaşık (1), tablo (1), bütün } \\
\text { (1), oran (1), altın oranı (1), matematik (1), geometrik şekil } \\
\text { (1), modifiye (1), evren (1), insan (1), gökyüzü (1), gökkuşa- } \\
\text { ğ (1), güneşin doğuşu (1), ay parçası (1) }\end{array}$ & 21 & 17,07 \\
\hline $\begin{array}{l}\text { Etkileyici varlık } \\
\text { olarak estetik }\end{array}$ & $\begin{array}{l}\text { Evren (4), çiçek (2), duygu (2), gün batımı (1), okyanus (1), } \\
\text { yeni doğan bebek (1), anne (1), güneşin batı̧ını izlemek (1), } \\
\text { kadın (1), güzel bir kız (1), dokunma (1), fayda (1), dünya (1), }\end{array}$ & 18 & 14,63 \\
\hline $\begin{array}{l}\text { Farklilık olarak } \\
\text { estetik }\end{array}$ & $\begin{array}{l}\text { Göz (3), iklim (1), yapı (1), evren (1), mevsim (1), yemek } \\
\text { (1), tablo (1), değişkenlik (1), siyasi görüş (1), yaşam biçimi } \\
\text { (1) takım tutmak (1) }\end{array}$ & 13 & 10,56 \\
\hline $\begin{array}{l}\text { Mutluluk kaynağı } \\
\text { olarak estetik }\end{array}$ & $\begin{array}{l}\text { Aşk (2), müzik (1), şiir (1), güneş (1), hoş koku (1), çiçek } \\
\text { (1), Messi'nin futbolu (1), yağmurda islanmak (1), mükem- } \\
\text { mellik (1), erguvan (1), sanat (1) }\end{array}$ & 12 & 9,75 \\
\hline $\begin{array}{l}\text { Sanat olarak } \\
\text { estetik }\end{array}$ & $\begin{array}{l}\text { Sanat (4), resim (2), heykel (2), bina (1), tarihi yapı (1), } \\
\text { Selimiye Camii (1), sihirli değnek (1) }\end{array}$ & 12 & 9,75 \\
\hline \multirow[t]{2}{*}{$\begin{array}{l}\text { Yansitma araci } \\
\text { olarak estetik }\end{array}$} & $\begin{array}{l}\text { Tablo (2), ayna (2), hayal gücü (1), çöldeki papatya (1), sarı } \\
\text { kırmızı (1), resim (1) }\end{array}$ & 8 & 6,50 \\
\hline & Toplam & 123 & 100 \\
\hline
\end{tabular}

Katılımcılar estetik değerine; "Güzellik temsili olarak estetik (39), "Uyum olarak estetik" (21), "Etkileyici varlık olarak estetik" (18), "Farkl1lı olarak estetik" (13), "Mutluluk kaynağı olarak estetik", (12), "Sanat olarak estetik (12), "Yansıtma aracı olarak estetik" (8) olmak üzere 7 kategoride metafor üretmiştir. Bir metafora ilişkin farklı katılımcıların farklı anlam yüklemeleri aynı metaforun farklı kategorilerde yer almasına neden olmuştur.

"Güzellik temsili olarak estetik" kategorisinde en çok metafor üretilmiştir. Bu metaforlar; güzellik (7), doğa (6), su (3), tavus kuşu (2), pırlanta (2), yaşam (2), çiçek (2), operasyon (2), yapaylık (2), vücut (1), okyanus (1), inci (1), yaratılmış varlık (1), yapı (1), mükemmellik (1), evren (1), bilgi (1), tablo (1), dış görünüş (1), sanat (1) şeklinde sıralanmaktadır. Bu kategoride yer alan bazı katılımcı ifadeleri aşağıda verilmiştir;

"Estetik vücut gibidir, çünkü insanın dış görünüşü, elbiseleri ve yüz güzelliği aklına gelir.” (E, 23)

"Estetik tavus kuşu gibidir, çünkü ilk bakışta bir şey anlaşılmaz, ancak saklı bir güzelliği vardır." $(\mathrm{K}, 107)$

"Estetik okyanus gibidir, çünkü ikisinin de içinde sayısız ve eşsiz güzellikler vardır." $(\mathrm{K}, 84)$

"Estetik inci gibidir, çünkü değerli ve kıymetli bir güzellik barındırır." $(\mathrm{K}, 76)$

"Estetik yaratılan varlık gibidir, çünkü Allah'ın yarattığı tüm canlılar güzellik taşır." (K, 81)

"Estetik mükemmellik gibidir, çünkü bir şeyin estetik olabilmesi için kusursuz ve mükemmel olması gerekir." (E, 109) 
“Estetik insan gibidir, çünkü dünya üzerinde insan olursa güzelleşir.” (K, 90)

"Estetik su gibidir, çünkü bütün güzel şeyler üzerine yansır çirkin olanlar dikkat çekmez" $(\mathrm{K}, 82)$

“Estetik doğa gibidir, çünkü doğa sahip olduklarıyla güzellik barındırır.” (K35)

"Estetik çiçeğe benzer, çünkü doğada çiçekler kusursuzdur. İnsanda her konuda en iyiye, kusursuz olana ulaşmak ister.” $(\mathrm{K}, 105)$

"Uyum olarak estetik" kategorisinde 21 katılımc1 17 farklı metafor tanımlamıştır. Bu metaforlar; doğa (3), güneş (2), deniz (2), sarmaşık (1), tablo (1), bütün (1), oran (1), altın oranı (1), matematik (1), geometrik şekil (1), modifiye (1), evren (1), insan (1), gökyüzü (1), gökkuşağı (1), güneşin doğuşu (1) ve ay parçası (1) şeklinde sıralanmaktadır. Bu kategori öğretmen adayları tarafından en çok metafor üretilen ikinci kategoridir. Aşağıda, bu kategoride yer alan bazı katılımcı ifadeleri verilmiştir;

“Estetik altın oranına benzer, çünkü hafif saparsa her şeyin dengesi bozulur”. (E, 3)

"Estetik matematik gibidir, çünkü her şeyin doğada düzenli bir şekilde belli bir doğrultuda aritmetik bir şekilde artıp azalması estetiktir.” (E, 46)

"Estetik geometrik şekil gibidir, çünkü estetik düzen uyum ve belli bir ölçü ister." $(\mathrm{K}, 100)$

"Estetik deniz gibidir, çünkü bir güzelliğin başka bir güzellik ile uyum sağlamas1 estetiktir." (E, 108)

"Estetik evrene benzer, çünkü evren birbiriyle ilişkili bağlantılı ve uyum içinde bir sistemdir.” (E, 54)

"Estetik doğaya benzer, çünkü doğa uyumlu ve uyumsuz her şeyi yapboz edasinda düzene oturtan canlı bir küredir.” $(\mathrm{K}, 43)$

"Estetik doğaya benzer, çünkü boğa dengeli uyumlu ve birbirine benzerdir". $(\mathrm{K}, 36)$

"Etkileyici varlık olarak estetik" kategorisi 18 katılımcı tarafından 13 farklı metaforla tanımlamıştır. Bunlar; evren (4), çiçek (2), duygu (2), gün batımı (1), okyanus (1), yeni doğan bebek (1), anne (1), güneşin batışını izlemek (1), kadın (1), güzel bir kız (1), dokunma (1), fayda (1) ve dünya (1) şeklinde sıralanmaktadır. Aşağıda, bu kategoride yer alan bazı katılımcı ifadeleri verilmiştir;

"Estetik gün batımına benzer, çünkü gün batarken oluşan o görüntü büyüleyici ve mest edicidir." $(\mathrm{K}, 91)$ 
"Estetik evrene benzer, çünkü kâinatın bakıldığında eşi ve benzeri olmayan bir tasarıma sahip olduğu görülür.” $(\mathrm{K}, 103)$

"Estetik çiçek gibidir, çünkü kokladığımızda veya hissettiğinizde sizde uyandırdığ 1 histen ibarettir." (K, 39)

"Estetik yeni doğan bebek gibidir, çünkü bebek her haliyle muazzam olarak ortaya çıkar.” (K, 104)

"Estetik güzel bir kıza benzer, çünkü güzel bir kıza bakarken onun ne kadar güzel ve hayranlık uyandırıcı olduğunu düşünürüz.” (E, 68)

"Estetik duyguya benzer, çünkü güzel olan bir obje insanda heyecan yaratmalıdir." (E, 70)

“Farklılık olarak estetik” kategorisini 13 katılımcı 11 metaforla tanımlamıştır. Bunlar; göz (3), iklim (1), yapı (1), evren (1), mevsim (1), yemek (1), tablo (1), değişkenlik (1), siyasi görüş (1), yaşam biçimi (1) takım tutmak (1) şeklinde sıralanmaktadır. Bu kategoriye ait oluşturulan metafor ifadelerinden bazıları aşağıdaki gibidir;

“Estetik göze benzer çünkü estetik öznel bir duygudur.” (K, 99)

"Estetik iklim gibidir çünkü her yıl dört farklı mevsim yaşanır iklim gibi estetik de değişir." (K, 102)

"Estetik insan gibidir çünkü bütün insanlar birbirinden farklıdır ve bu farklılıkların hepsi kendi içinde güzellikler barındırır.” (E, 55)

"Estetik mevsim gibidir çünkü herkesin mevsim sevgisi farklıdır. Bazıları kışı bazıları ilkbaharı sever estetik de böyledir. İnsanlar kişilikleriyle bakış açıları ile estetik algıları değişir.” (K, 117)

"Estetik yemek gibidir çünkü her yörede farklı lezzetler tatlar vardır. Damak zevki kişiden kişiye değişir.” $(\mathrm{K}, 80)$

"Estetik tablo gibidir çünkü estetik göreceli bir kavramdır. Bir kişiye güzel ve estetik gelen tablo başka bir kişiye güzel gelmeyebilir.” (E, 48)

"Estetik değişkenlik gibidir çünkü her zaman aynı şeyi beğenmeyebiliriz kendimiz hariç beğenmeniz değişir.” $(K, 44)$

"Estetik siyasi görüşe benzer çünkü kişiden kişiye farklı bakış açıları vardır." $(\mathrm{E}, 120)$

"Estetik yaşam biçimi gibidir çünkü her insanın yaşayış biçimi farklılık gösterir.” $(K, 33)$ 
"Estetik takım tutmak gibidir çünkü takım tutmak sorgulanmaz kişiden kişiye farklılık gösterir.” (E, 69)

"Estetik evren gibidir çünkü evrenin sonsuz güzelliğini anlayan insanın dünyaya bakışı farklıdır.” (K, 89)

"Mutluluk kaynağı olarak estetik" kategorisinde 12 katılımc1 11 farklı metafor imgesi tanımlamıştır. Bu metaforlar; aşk (2), müzik (1), şiir (1), güneş (1), hoş koku (1), çiçek (1), Messi'nin futbolu (1), yağmurda islanmak (1), mükemmellik (1), erguvan (1) ve sanat (1) şu şeklinde sıralanmıştır. Aşağıda, bu kategoride yer alan bazı katılımcı ifadeleri verilmiştir;

"Estetik müziğe benzer, çünkü müziğin ritmi doğru oluşturulduğunda ortaya haz veren bir şey çıkar.” $(K, 83)$

“Estetik güneş gibidir, çünkü güneşin varlığı hoşumuza gider bize zevk verir.” $(\mathrm{K}, 71)$

"Estetik aşk gibidir, çünkü aşk insana tutkuyla anlamlı bakmayı öğretir.” (E, 53)

“Estetik hoş koku gibidir, çünkü parfüm kokuları insanın hoşuna gider.” (K, 96)

"Estetik çiçek gibidir, çünkü insan çiçeğe baktıkça ve onunla ilgilendikçe daha mutlu ve huzurlu olur." (K, 78)

“Estetik Messi’nin futbol oyunu gibidir, çünkü onun topla buluşması insana mutluluk veriyor." (E, 18)

“Estetik yağmurda ıslanmak gibidir, çünkü yağmurda 1slanmayı sevenler bu durumdan zevk duyarlar.” $(\mathrm{K}, 21)$

"Estetik bir erguvan ağacına benzer, çünkü erguvan ağacı göze hitap eder ve mutluluk verir.” (E, 116)

"Sanat olarak estetik" kategorisini 12 katılımcı 7 farklı metaforla tanımlamıştır. Bunlar; sanat (4), resim (2), heykel (2), bina (1), tarihi yap1 (1), Selimiye Camii (1), sihirli değnek (1) şeklindedir. Aşağıda, bu kategoride yer alan bazı katılımcı ifadeleri verilmiştir;

“Estetik sanata benzer, çünkü bir sanatçının elinden çıkan öznel göze hitap eden bir görüntüdür.” (E, 25)

"Estetik heykele benzer, çünkü bir hamura şekil verilmesi onun ince ayrıntısına kadar düşünülmesidir.” (K, 77)

"Estetik sanat gibidir, çünkü yapan kişi işinin ehli olmalı ve hamuru iyice yoğurup şekil vermelidir.” $(\mathrm{K}, 75)$

“Estetik bina gibidir, çünkü belli kriterler çevresinde sanata uygun biçimde ya- 
pılmış bir yapıdır." $(\mathrm{K}, 34)$

"Estetik tarihi bir yapı gibidir, çünkü bu yapılar insan tarafından ortaya koyulan bir eserdir." (E, 24)

“Estetik Selimiye Camii'ne benzer, çünkü zaman geçse de bu cami özünü korur." $(\mathrm{E}, 66)$

"Estetik sihirli bir değnek gibidir, çünkü tıpkı sihirli bir değnek ile dokunurmuşçasına emek verilmiş sıradanlıktan çıkarılmış bir eser ortaya çıkar.” (E, 61)

"Yansitma aracı olarak estetik" kategorisini 8 katılımc1 6 farklı metaforla tanımlamıştır. Bunlar; tablo (2), ayna (2), hayal gücü (1), çöldeki papatya (1), sarı kırmızı (1) ve resim (1), şeklindedir. Aşağıda, bu kategoride yer alan bazı katılımcı ifadeleri verilmiştir;

"Estetik, tabloya benzer, çünkü kişiler, çevresinde gördüklerini tabloya yansıtır." (K, 19)

"Estetik aynaya benzer, çünkü duygularımızı görünebilir kılar duyguları konuşturur." (K, 5)

"Estetik hayal gücü gibidir, çünkü sanatı gerçekleştirmek için hayal gücü güçlü olmalıdır." (E,30)

"Estetik ayna gibidir, çünkü aynanın yansıtma özelliğinin olması için arkasındaki sıra ihtiyacı vardır. Estetiğinde kendisini gösterebilmesi için çirkine ve kötüye ihtiyacı vardır.” (K, 37)

"Estetik çöldeki papatyaya benzer, çünkü estetik bakmaktır baktığını hayal ettiği gibi veya olduğu gibi görmektir.” (E, 114)

"Estetik sarı ve kırmızıya benzer, çünkü bu renkler çoğu insana aynı hisleri yansitır." (E, 67)

Araştırmanın üçüncü sorusu öğretmen adaylarının cinsiyetleri bakımından kavramsal kategoriler farklılık göstermekte midir? şeklindedir. Buna ilişkin katılımcılar tarafindan ileri sürülen metaforların cinsiyete göre dağılımı Tablo 3 'te sunulmuştur.

\begin{tabular}{llllllc}
\hline Tablo 4. Estetik Değerine İlişkin Metaforların Cinsiyete Göre Dağılımı & & & \\
\hline Kategoriler & Kadın (n) & $\mathbf{\%}$ & Erkek (n) & $\mathbf{\%}$ & Toplam & $\mathbf{\%}$ \\
\hline Güzellik temsili olarak estetik & 24 & 19,51 & 15 & 12,19 & 39 & 31,70 \\
\hline Uyum olarak estetik & 12 & 9,75 & 9 & 7,31 & 21 & 17,07 \\
\hline Etkileyici varlık olarak estetik & 11 & 8,94 & 7 & 5,69 & 18 & 14,63 \\
\hline Farklılık olarak estetik & 9 & 7,31 & 4 & 3,25 & 13 & 10,56 \\
\hline Mutluluk kaynağı olarak estetik & 8 & 6,50 & 4 & 3,25 & 12 & 9,75 \\
\hline Sanat olarak estetik & 7 & 5,69 & 5 & 4,06 & 12 & 9,75 \\
\hline Yansitma aracı olarak estetik & 4 & 3,25 & 4 & 3,25 & 8 & 6,50 \\
\hline Toplam & $\mathbf{7 5}$ & $\mathbf{6 0 , 9 7}$ & $\mathbf{4 8}$ & $\mathbf{3 9 , 0 2}$ & $\mathbf{1 2 3}$ & $\mathbf{1 0 0}$ \\
\hline
\end{tabular}


Katılımcıların ileri sürdükleri metaforların cinsiyete göre dağılımlarına bakıldığında "Yansıtma aracı olarak estetik" kategorisinde erkek ve kadın katılımcıların sayısının eşit olduğu, diğer kategorilerde kadın katılımcıların sayısının daha çok olduğu görülmektedir. Ayrıca tüm kategorilerde kadın ve erkek katılımcıların estetik kavramına metafor geliştirdiği anlaşılmaktadır.

\section{Sonuç ve Öneriler}

$\mathrm{Bu}$ araştırma sosyal bilgiler öğretmeni adaylarının estetik değerine ilişkin alg1larını metaforlar yoluyla ortaya çıkarmayı amaçlamıştır. Verilerin analizi sonucunda estetik değerine yönelik 69 geçerli metafor geliştirildiği belirlenmiştir. Bu metaforlar; "güzellik temsili olarak estetik", "uyum olarak estetik", "etkileyici varlık olarak estetik", "farklılık olarak estetik", "mutluluk kaynağı olarak estetik", "sanat olarak estetik", "yansitma aracı olarak estetik" olmak üzere 7 kategoride dağılım göstermiştir. Çalışmada aynı metaforun birden çok kategoride yer alması metafora farklı kişilerin farklı anlam verdiklerine işaret edebilir. Aynı zamanda estetik kavramının açıklanmasında çok sayıda metafora ihtiyaç duyulduğunu da göstermektedir.

Araştırma, sosyal bilgiler öğretmen adaylarının büyük çoğunluğunun "estetik" değerini; güzelliği temsil eden araç, doğa ve yaşama dair uyum, etkileyici, mutluluk verici varlık olarak algıladıklarını göstermektedir. Estetik değeri için en çok; “doğa" (9), "güzellik" (7), "evren" (7) ve "sanat" (6) metaforları geliştirilmiştir.

Kılcan ve Akbaba (2014) yaptıkları araştırmada 8. sınıf düzeyinde alt düzey sosyo-ekonomik seviyede olan öğrencilerin estetik kavramını en çok "Ajda Pekkan" (5) ve "güzellik" (3), orta düzey sosyo-ekonomik seviyedeki öğrencilerin "Bülent Ersoy" (9) ve "Ajda Pekkan" (8), üst düzey sosyo-ekonomik seviyedeki öğrencilerin ise "güzellik" (11), "ameliyat" (3) ve "değişim” (2) şeklinde algıladıklarını belirtmişlerdir. Öğrencilerin estetik kavramını; doğal olanı kapatan, değiştirmeden kaynaklı olumsuzluk ve uğraşınca bozulan" şeklinde cerrahi bir müdahale olarak yanlış olarak algıladıklarını ileri sürmüşlerdir.

Güzellik kavramı benzerliği dışında Kılcan ve Akbaba'nın (2014) çalışmasında ve bu çalışmada çok sayıda kategori ve metafor farklılık göstermektedir. Bu farkl1lık yaş, cinsiyet ve sosyo-kültürel düzey gibi birçok faktörden kaynaklanıyor olabilir. Nitekim Brisard (2002), bir anlam nesnesi olarak metaforların öncelikle bir temsil problemi sunduğu ve onu ifade eden kişinin dilsel, bilişsel, duyuşsal ve sosyo-kültürel düzeyinden etkilendiğini belirtmektedir. Diğer bir deyişle metafor 
kendisini üretenin tutumları, duyguları ve değerlendirmeleriyle uyumlu olduğundan onu geliştirenin sosyal kimliği hakkında da perspektif sunar.

Demirel (2018), Kılcan ve Akbaba'nın (2014) çalışmasına benzer bir şekilde 9-12 yaş çocuklarının estetik kavramını genel olarak cerrahi bir müdahale, fiziksel görünüm ya da esneklik olarak algıladıklarını ifade etmektedir. Aynı çalışmada estetik kavramı, cerrahi müdahele kategorisinde "estetik ameliyat" (156), fiziksel görünüm kategorisinde "güzellik", doğa güzelliği kategorisinde "çiçek" (46) ve esneklik kategorisinde "lastik" (35) metaforu ile tanımlanmıştır. Sanatsal anlamda kişiye zevk ya da heyecan veren bir duygu olarak da estetik kavramına ilişkin tablo (9); eşya (6) renk (19), kişilik yapısı (2) ve güzel huy (2) metaforları belirtilmiştir. Bu çalışmada ise estetik kavramına "opererasyon" ve "yapaylık" metaforu ikişer kişi tarafindan belirtilmiştir. Bu sonuç estetik kavramına ilişkin doğal olanı bozmak için yapılan bir girişim gibi yanlış algının çalışmada çok düşük düzeyde kaldığını göstermektedir. Nitekim öğretmen adaylarının büyük çoğunluğu estetik değerini güzelliği temsil eden nesneler, doğada yaşamı kolaylaştıran, doğanın devamını sağlayan uyum ve ahenk özellikleri ile ilişkilendirmiştir. Atasoy (2005), insanların doğaya karşı olan duygu, düşünce, ilgi tutum ve davranışlarında onların doğuştan gelen özellikleri ile eğitim, sosyal, kültürel, ekonomik, dini özelliklerin de etkili olduğu belirtmektedir.

Güzellik temsili olarak estetik kategorisinde güzellik (7), doğa (6), su (3), tavus kuşu (2), pırlanta (2), yaşam (2), çiçek (2) olarak üretilen metaforlar; "estetik tavus kuşu gibidir, çünkü ilk bakışta bir şey anlaşılmaz ancak saklı bir güzelliği vardır.", "estetik doğa gibidir, çünkü doğa sahip olduklarıyla güzellik barındırır." "estetik çiçeğe benzer, çünkü doğada çiçekler kusursuzdur, insanda her konuda en iyiye kusursuz olana ulaşmak ister." cümleleri ile desteklenmiştir. Buradan öğretmen adaylarının estetik kavramını doğada bulunan canlı ve cansız nesneler ve bu nesnelerin güzellikleri ile ilişkilendirdikleri anlaşılmaktadır. Bu kategoride estetik kavramı doğanın özellikleri olan güzel, göze hoş gelen sanatsal ve estetik değeri olan bir unsur olarak algılanmaktadır. Buna göre estetik değeri soyut ve karmaşık anlamına rağmen doğanın sanatsal ve estetik yönüne yönelik metaforlara vurgu yapılarak doğanın sadece ihtiyaçların karşılandığı bir yaşam alanı olmadığı duygusal sanatsal ve estetik özelliklerinin de vurgulandığını göstermektedir. Kahyaoğlu (2015) çalışmasında ilköğretim öğrencileri doğayı; canlı ve cansız birçok hayvan ve bitki türlerinin yaşadığı zengin bir yaşam alanı olarak ve manzaralı, temiz, güzel, göze hoş gelen olarak niteleyerek doğanın estetik ve sanatsal yönünü vurgulamışlardır. Estetik kavramı için belirtilen doğa metaforları bu çalışmadaki bulgularla örtüşmektedir. 
Uyum olarak estetik kategorisinde doğa (3), güneş (2), deniz (2), sarmaşık (1), tablo (1), bütün (1), oran (1), altın oran1 (1), matematik (1), geometrik şekil (1), modifiye (1), evren (1), insan (1), gökyüzü (1), gökkuşağ 1 (1), güneşin doğuşu (1) ve ay parçası (1) metaforları ile temsil edilen estetik değeri "Estetik doğaya benzer, çünkü doğa uyumlu ve uyumsuz her şeyi yapboz edasında düzene oturtan canlı bir küredir.”, Estetik geometrik şekil gibidir, çünkü estetik düzen uyum ve belli bir ölçü ister." cümleleri ile de açıklanmıştır. Burada sosyal bilgiler öğretmen adaylarının estetik değerini denge, ahenk ve uyum olarak doğayı ilişkin özelliklerle açıklamaya çalıştıkları görülmektedir. Kahyaoğlu (2015) çalışmasında ilköğretim öğrencilerinin doğa kavramına ilişkin doğanın dengesi ve kuralları kategorisinde az sayıda metafor ürettiğini belirtmiştir. Buna sebep olarak da doğanın madde döngüsü, enerji alış-verişi, yaşam birliktelikleri, tür içi ve tür dışı ilişkileri, ekosistemler ve bunların çalışma mekanizmalarının anlaşılmasının zor olmasından kaynaklanabileceğini ileri sürmüştür. Ayrıca doğayı kavramaya yönelik metafor kullanılmasının doğanın işlevini anlama açısından önemli olabileceğini belirtmiştir.

Kahyaoğlu ve Kırıktaş (2016) ortaöğretim ve üniversite öğrencilerinin doğayı canlı ve cansız elemanlarıyla bir ekosistem, bitkisel unsurların bulunduğu bir yaşam alanı, canlıların yaşamlarını sürdürdüğü bir ortam olarak algıladıklarını ortaya koymuşlardır. Ancak ortaokul ve üniversite öğrencilerinin eğitim düzeylerine göre kullandıkları metaforların üniversite öğrencileri lehine anlamlı derecede farklılık gösterdiğini belirtmişlerdir. Üretilen metaforların cinsiyete göre ortaöğretim düzeyinde farklı iken üniversite düzeyinde farklılık göstermediğini belirtmişlerdir.

Etkileyici varlık olarak estetik, kategorisinde evren (4), çiçek (2), duygu (2), gün batımı (1), okyanus (1), yeni doğan bebek (1), anne (1), güneşin batışını izlemek (1), kadın (1), güzel bir kız (1), dokunma (1), fayda (1) ve dünya (1) şeklinde şeklinde geliştirilen metaforlar "estetik evrene benzer, çünkü kâinatın bakıldığında eşi ve benzeri olmayan bir tasarıma sahip olduğu görülür.”, "estetik yeni doğan bebek gibidir, çünkü bebek her haliyle muazzam olarak ortaya çıkar.” açıklamaları ile desteklenmiştir. Estetik kavramının soyut ve karmaşık anlamına rağmen doğanın sanatsal ve estetik yönüne yönelik metaforlara vurgu yapılarak doğanın sadece ihtiyaçlarımızın karşılandığı bir yaşam alanı olarak değil duygusal sanatsal ve estetik özellikleri ile de algılandığı söylenebilir.

Farklılık olarak estetik kategorisinde göz (3), iklim (1), yapı (1), evren (1), mevsim (1), yemek (1), tablo (1), değişkenlik (1), siyasi görüş (1), yaşam bi- 
çimi (1) takım tutmak (1) metaforları "estetik göze benzer çünkü estetik öznel bir duygudur.", "estetik iklim gibidir çünkü her yıl dört farklı mevsim yaşanır, iklim gibi estetik de değişir." cümleleri ile desteklenmiştir.

Mutluluk kaynağı olarak estetik kategorisinde aşk (2), müzik (1), şiir (1), güneş (1), hoş koku (1), çiçek (1), Messi'nin futbolu (1), yağmurda sslanmak (1), mükemmellik (1), erguvan (1) ve sanat (1) metaforları "estetik müziğe benzer, çünkü ritmi doğru oluşturulduğunda ortaya haz veren bir şey çıkar.", "estetik güneş gibidir, çünkü güneşin varlığı hoşumuza gider bize zevk verir." ifadeleri ile açıklanmıştır. Buradan sosyal bilgiler öğretmen adaylarının estetik kavramını bir taraftan doğaya ilişkin denge, ahenk, uyum, yaşam gibi kavramlarla açıklarken diğer taraftan sanatsal güzellik ve doğa güzelliği olarak canlı veya cansız varlıkların şaşkınlık, hayranlık, güzellik ve beğeni gibi duyguları uyandiran insanı etkilen, insana zevk, heyecan ve mutluluk veren kavramlarla da ilşkilendirdiği anlaşılmaktadır.

"Sanat olarak estetik" kategorisi; sanat (4), resim (2), heykel (2), bina (1), tarihi yap1 (1), Selimiye Camii (1), sihirli değnek (1) olarak belirtilen metaforlar "estetik sanata benzer, çünkü bir sanatçının elinden çıkan öznel göze hitap eden bir görüntüdür.", "estetik resme benzer, çünkü istediğin parçayı kalemi kullanır, sonucunda güzel bir ürün elde edilir.", "estetik heykele benzer, çünkü bir hamura şekil verilmesi onun ince ayrıntısına kadar düşünülmesidir." cümleleri ile desteklenmiştir.

Yansitma aracı olarak estetik kategorisinde; tablo (2), ayna (2), hayal gücü (1), çöldeki papatya (1), sarı kırmızı (1) ve resim (1) olarak belirtilen metaforlar "estetik tabloya benzer, çünkü bir manzaraya bakarak oluşturduğu tablonun gördüklerini sanatsal çerçevesinde kâğıda yansımasıdır.", "estetik aynaya benzer, çünkü duyguları görünebilir kılar duyguları konuşturur." ifadeleri ile açıklanmıştır. Hiçyılmaz ve Adanır (2019) çalışmalarında öğretmen adaylarının sanat kavramına ilişkin belirttikleri kategorilerden "yaratıcıllğın bir ifadesi olarak sanat" ve "yansıtıcı bir özellik olarak sanat" kategorilerinde sanat kavramına yükledikleri anlamlar bu çalışmada "sanat olarak estetik" ve "yansıtma aracı olarak estetik" kategorilerindeki metaforlar birebir aynı olmasa da metaforların yönleri bakımdan benzerlik göstermektedir. Örneğin Hiçyılmaz ve Adanır'ın (2019) çalışmalarında öğretmen adayları sanat kavramına "sanat insan gibidir. Çünkü sanat biriciktir. Tipkı insanlar gibi aynı özellikte başka bir benzeri yoktur.", "sanat gökkuşağı gibidir. Çünkü güzel renkler bir araya gelerek güzel bir görünüm sağladığı gibi sanatta da renkler bir araya gelerek güzel bir görünüm sağlayabilir, "sanat hayal gibidir. Çünkü sanat yoluyla hayalimizdekileri dile- 
diğimiz şekilde sunabiliriz", yansıtıcı bir özellik olarak ise sanatı "sanat ayna gibidir. Çünkü ayna her şeyi yansıtabiliyorsa sanat da insandaki düşünceleri ve duygular yansıtır" sanat film gibidir. Çünkü filim sanat gibi yönetmenin hayal dünyasındaki yansımalarıdır" şeklinde metaforlar ve açıklamalar yapmışlardır.

Öğretmen adaylarının ileri sürdükleri metaforların cinsiyete göre dağılımlarına bakıldığında kategorilerin hepsinde kadın ve erkek katılımcıların metafor geliştirdikleri görülmektedir. Üretilen metafor sayısı açısından "yansıtma aracı olarak estetik" kategorisinde kadın ve erkek öğretmen adayları eşit sayıda metafor geliştirmiştir. Diğer kategorilerde kadın katılımcılar daha çok metafor üretmiştir. Kadın katılımcıların estetik algılarının daha yüksek olmasında çevrelerinde bulunan nesne ya da varlıklara güzellik algılarının farklı olması ve daha dikkatli bir şekilde gözlem yapmaları etkili olmuş olabilir. Nitekim Demirel, (2018) yaptığı çalışmada kız öğrencilerin erkek öğrencilere göre çevrelerinde gözlemledikleri sanatsal ve kültürel güzelliklere ilişkin bakış açılarının ve farkındalıklarının daha olumlu olmasında, değer algısının yaşanılan çevre ve değer yargıları ile ilişkili olduğunu belirtmiştir. Demirel, (2018) bu durumu kişilerin yaş aldıkça bakış açılarının ve güzel kavramını algılama eğilimlerinin değişmesi ile açıklamıştır. Göreceli bir kavram olan güzel ifadesinin üzerine düşünmenin de kişiden kişiye ve yaş düzeyine bağlı olarak farkl1laşabileceğinin bir göstergesi olarak da yorumlanabileceğini ifade etmiştir. Araştırma bulguları genel olarak değerlendirildiğinde estetik değerine ilişkin geliştirilen metafor sayısı bakımından kadın katılımcıların lehine olan durumun nedenleri hakkında yeni çalışmalar yapılabilir. Farklı sınıf düzeylerinde estetik değerine yönelik metaforların belirlendiği yeni çalışmalarla alan yazın geliştirilebilir. Ayrıca farklı veri toplama araçları kullanılarak estetik değeri ile ilişkili ayrıntılı çalışmalar yürütülebilir.

\section{Kaynakça}

Akhan, N. E. (2013). Sosyal bilgiler öğretmen adaylarının sanat algıları ve sanat konularının öğretimine yönelik görüşleri. Uşak Üniversitesi Sosyal Bilimler Dergisi, 146-162.

Akhan, N., E., Kılıçoğlu, G. ve Gedik, H. (2014). Sosyal bilgiler öğretmenliği birinci sınıf öğrencilerinin sosyal bilgiler ve sosyal bilimlere yönelik metaforları. Turkish Studies, 9(8), 73-90.

Artut, K. (2013). Sanat eğitimi kuramları ve yöntemleri (6. Bask1). Anı Yayıncılık.

Atasoy, E. (2005), Çevre için eğitim: ilköğretim öğrencilerinin çevresel tutum ve çevre bilgisi üzerine bir çalışma (Yayınlanmamış doktora tezi). Uludağ Üni- 
versitesi Sosyal Bilimler Enstitüsü, Bursa.

Bengisu, H. (2011). Estetik yaşam. 38. ICANAS Bildirileri: Kültürel Değişim, Gelişim ve Hareketlilik Cilt I (ss. 99-106). Atatürk Kültür, Dil ve Tarih Yüksek Kurumu Yayınları.

Biscotte, S. (2015). The necessity of teaching for aesthetic learning experiences in undergraduate general education science. The Journal of General Education, 64(3), 242-256. https://doi.org/10.1353/jge.2015.0017

Bolton, S. L. (1973). Oral language production as an aid to aesthetic learning. Art education, 14-15. https://doi.org/10.2307/3191817

Brainerd, S. M. ve Marshall H. J. (1976). A currıculum for an aesthetic program for teacher education. Review of Research in Visual Arts Education, 3(1), 48-53. https://www.jstor.org/stable/20715204

Brisard, F. (2002). Metaphors are events, not objects. Jezikoslovlje, 3(1-2), 17-39. https://hrcak.srce.hr/index.php?show=clanak\&id_clanak_jezik=49687

Çalışkan, N. (2009). Metaforların izinde bir yazarın kavram dünyasına giriş: Cemil Meriç'in bu ülke'sinde kitap metaforları, Dil Araştırmaları, 4, 87-100.

Çelikkaya, T. ve Yakar, H. (2015). Perceptions of social studies preservice teachers related to the concept of social studies: metaphor analysis sample. International Online Journal of Educational Sciences, 7(4), 188-207. https://doi. org/10.15345/iojes.2015.04.013

Cevizci, A. (1999). Felsefe sözlüğü. Paradigma Yayınları.

Demirel, İ. N. (2018). 9-12 yaş çocukların estetik değer algılarının incelenmesi. İönü Üniversitesi Eğitim Fakültesi Dergisi, 19(2), 312-327. https://doi. org/10.17679/inuefd.34672

Demirkaya, H. ve Çal, Ü. T. (2018). Sosyal bilgiler öğretmen adaylarının dürüstlük değerine ilişkin metaforik algıları, Kırşehir Eğitim Fakültesi Dergisi, 19(3), 1964-1980. https://doi.org/10.29299/kefad.2018.19.03.005

Deniş Çeliker, H. ve Akar, A. (2015). Ortaokul öğrencilerinin doğaya ilişkin metaforları. Ahi Evran Üniversitesi Kırşehir Eğitim Fakültesi Dergisi (KEFAD), 16(2), 101-119.

Eaton, M. M. ve Moore, R. (2002). Aesthetic experience: its revival and its relevance to aesthetic education. The Journal of Aesthetic Education, 36(2), 9-23. https://doi.org/10.2307/3333754

Ergün, M. (2010). Estetik (Sanat felsefesi). http://mustafaergun.com.tr/wordpress/ wp-content/uploads/2015/11/sanatfelsefesi.pdf 
Ertürk, R. (2017). İlkokul öğrencilerinin “öğretmen” kavramına ilişkin metaforik algıları. E-Uluslararası Eğitim Araştırmaları Dergisi, 8(3x), 1-15. https:// doi.org/10.19160/ijer.285232

Gökay, M. (2005). İlköğretim resim-iş eğitiminde çok alanlı sanat eğitimi yönteminin uygulanması. Ed. Vedat Özsoy. İlköğretim sanat eğitimi kuramlarl ve yöntemleri (ss. 75-100). Görsel Sanatlar Eğitimi Derneği Yayınları

Gültekin, M. (2013). İlköğretim öğretmen adaylarının eğitim programı kavramına yükledikleri metaforlar. Eğitim ve Bilim, 38(169), 126-141.

Gültekin, T. (2011). Sanat eğitiminde estetik değerlerin gelişimi sürecinde çocuk ve iletişim. Akademik Bakış Dergisi, (24), 32-39.

Hiçyılmaz, Y. ve Adanır, Y. (2019). Sanat eğitimi dersi alan öğretmen adaylarının sanat kavramına ilişkin sahip oldukları algıların metaforlar aracılığıyla incelenmesi. Anemon Muş Alparslan Üniversitesi Sosyal Bilimler Dergisi, 7(3), 9-23. https://doi.org/10.18506/anemon.462012

Jakobson, B. ve Wickman, P. O. (2008). Art in science class vs science in art class: a Study in Elementary School. In Education\&didactique, 2(3), 141-157. https://doi.org/doi:10.4000/educationdidactique.396

Johnson, M. H. (1998). Phenomenological method, aesthetic experience, and aesthetic education. The journal of aesthetic education, 32(1), 31-41. https://doi. org/10.2307/3333206

Kahyaoğlu, M. (2015). İlköğretim öğrencilerinin doğa kavramına ilişkin algılarının metaforlar yoluyla incelenmesi. Turkish Studies, 10(11), 831-846. https:// doi.org/10.7827/TurkishStudies.8526

Kahyaoğlu, M. ve Kırıktaş, H. (2016). Ortaöğretim ve üniversite öğrencilerinin "doğa" kavramına ilişkin algılarının metafor analizi yoluyla incelenmesi. Marmara Coğrafya Dergisi, 33, 58-76. https://doi.org/10.14781/mcd.98568

Kalın Ulu, Ö. Koçoğlu, E. (2017). Sosyal bilgiler öğretmen adaylarının bağımsızlık değerine karşı metaforik algıları. Ahi Evran Üniversitesi Kırşehir Ĕgitim Fakültesi Dergisi (KEFAD), 18(2), 419-434.

Kan, Ç. (2010). Sosyal bilgiler dersi ve değerler eğitimi. Millî Ĕ̆itim, 187, 138-145.

Karaahmet Balc1, S. (2015). Sanat eğitimi alan bireylerde estetik algı oluşturmak için görsel kültür eğitiminin gerekliliği. The Journal of Academic Social Science Studies, 36, 465-477. https://doi.org/10.9761/JASSS2872

Kaya, M. F. (2014). Sosyal bilgiler öğretmen adaylarının çevre sorunlarına ilişkin algıları: metafor analizi örneği. Turkish Studies, 9(2), 917-931. https://doi. org/10.7827/TurkishStudies.6308 
Kerdeman, D. (2005). Aesthetic experience and education: themes and questions. The Journal of Aesthetic Education, 39(2), 88-96. https://doi.org/10.1353 / jae.2005.0012

Kilcan, B. ve Akbaba, B. (2014). Sosyal bilgiler öğretim programinda yer alan estetik değerine ilişkin öğrenci algilarinin incelenmesi. Ĕgitimde Kuram ve Uygulama. 10(4), 1047-1076.

Kıncal, R., Y. (2007). Vatandaşlık bilgisi (2. Baskı). Nobel Yayınları.

Koçoğlu, E. (2014). Sosyal bilgiler öğretmenlerinin sosyal bilgiler kavramına ilişkin imgesel algıları, Ahi Evran Üniversitesi Kırşshir Eğitim Fakültesi Dergisi, 15(3), 107-126.

Lachapelle, R., Murray, D. ve Neim, S. (2003). Aesthetic understanding as informed experience: the role of knowledge in our art viewing experiences. The Journal of Aesthetic Education, 37(3), 78-98. https://doi.org/10.1353/ jae.2003.0022

Mazman Budak, F. (2012). Sosyal bilgiler dersinde (7. sinıf) doğal ve kültürel varlıklar aracılı̆̆ ile estetik de ğer ĕgitimi (Tokat Örneği) (Yayınlanmamış doktora tezi). Atatürk Üniversitesi, Erzurum.

Meral, E., Küçük, B. ve Gedik, F. (2016). Sosyal bilgiler öğretmen adaylarının çevre kavramına ilişkin metaforik algıları. Kastamonu Ĕ̆itim Dergisi, 24(1), 65-78. https://dergipark.org.tr/tr/pub/kefdergi/issue/22606/241618

Miles, J. B. (1962). Aesthetic learning through experiences in a correlated program of instruction in art, music and modern dance. Studies in Art Education, 4(1), 34-45. https://doi.org/10.2307/1319704

Miles, M. B. ve Huberman, A. M. (2016). Nitel veri analizi (2nd edit). S. Akbaba Altun, \& A. Ersoy (Eds.). Pegem Akademi.

Milli Eğitim Bakanlığı. (2016). Güzel sanatlar lisesi öğretim programı sanat eserleri analizi dersi. http://mufredat.meb.gov.tr/Dosyalar/201992519333372sanat $\% 20$ Eserleri\%20Analizi.pdf

Milli Eğitim Bakanlığı. (2018). Sosyal bilgiler dersi ögretim programı (İlkokul ve ortaokul 4, 5, 6 ve 7. siniflar). http://mufredat.meb.gov.tr/ProgramDetay. aspx?PID=354.

Montague, P. (1979). Learning aesthetic concepts and justifying aesthetic judgments. The Journal of Aesthetic Education, 13(1), 45-52. https://doi. org/10.2307/3332088

Özalp, K. (2016), Güzelin bilinçli algısı ve estetik eğitimi. İdil. 5(21), 491-504.

Özbal, N. ve Aydoğan, İ . (2017). Eğitimde estetiğin gerekliliği ve oluşumu üzerine 
bir inceleme. Kırlkkale Üniversitesi Sosyal Bilimler Dergisi, 7(2), 249-260.

Patton, M. Q. (2018). Nitel araştırma ve değerlendirme yöntemleri (Mesut Bütün, Selçuk Beşir Demir Çev. Ed.). Pegem Akademi.

Saban, A. (2008). Okula ilişkin metaforlar. Kuram ve Uygulamada Eğitim Yönetimi, $55,459-496$.

Tuna Er, Y. ve Mazman Budak, F. (2013). Sosyal bilgiler öğretmen adaylarının "tarih” kavramına ilişkin algılarının mecazlar/ metaforlar yardımıyla analizi. Adıyaman Üniversitesi Sosyal Bilimler Enstitüsü Dergisi, 14, 609-642. https://doi.org/10.14520/adyusbd.600.

Tunalı, İ. (2004). Estetik. Remzi Kitapevi.

Türk Dil Kurumu (2019). Güncel Türkçe sözlük. https://sozluk.gov.tr/

Uhrmacher, P. B. (2009). Toward a theory of aesthetic learning experiences. Curriculum Inquiry, 39 (5), 613-636. https://www.jstor.org/stable/20616455

Uludağ, Z. ve Odac1, H. (2002). Eğitim öğretim faaliyetlerinde fiziksel mekan, Milli Eğitim Dergisi, Kış-Bahar Sayı, 153-154.

Wong, D. (2007). Beyond control and rationality: Dewey, aesthetics, motivation, and educative experiences. Teachers College Record, 109(1), 192-220. https://people.wou.edu/ girodm/middle/Wong-TCRBeyondControl.pdf

Yıldırım, A. ve Şimşek, H. (2016). Sosyal bilimlerde nitel araştırma yöntemleri (11. Baskı). Seçkin Yayınları. 
Extended Abstract

\section{Social Studies Prospective Teachers' Metaphoric Perceptions about the Value of Aesthetics}

Ayşe SEYHAN, Corresponding Author, Assistant Professor.

Recep Tayyip Erdoğan Universty, Faculty of Education, Rize/Turkey.

ayse.seyhan@erdogan.edu.tr

http://orcid.org/0000-0003-1741-4878

Article Type: Research Article

https://doi.org/10.34234/ded.714332

Received Date: 03.04 .2020

Accepted Date: 10.07 .2020

Published Date: 25.12 .2020

\section{Introduction}

Aesthetics is "a way of thinking that evaluates art and works of art" and defines the origin, nature, value of the beauty of art while examining the attitudes and behaviors of people against these values (Artut, 2013). Aesthetic value understanding and aesthetic value acquisition differ according to individuals' relationships and experiences with the environment (Wong, 2007). Aesthetic value is influenced by education, culture, social gains, good and bad experiences, beliefs and the environment (Montague, 1979; Artut, 2013). Aesthetic education is to acquire a person with the discipline to perceive the enjoy beauty through experiences. Aesthetic education not only provides people with elegance, nobility, and politeness, but also makes people sensitive to the events around them (Özalp, 2016). Aesthetic value develops with the senses. Senses work together with reason, curiosity, and relevance. The individual has an aesthetic experience 
by perceiving the object through sensory experience, connecting with the object. Teachers should create opportunities to provide students with an aesthetic learning experience (Uhrmacher, 2009). According to the 2018 Social Studies Curriculum, students who complete primary school should gain aesthetic sensitivity. The purpose of this research is to reveal prospective social studies teachers' perceptions of the "aesthetic" value through metaphors. For this purpose, answers to the following questions were sought:

- What are the metaphors that teacher candidates have regarding the concept of aesthetics?

- Under which conceptual categories can the metaphors related to aesthetic value be collected in terms of their common features?

- Do the conceptual categories differ in terms of the gender of teacher candidates?

\section{Method}

In this study, which was designed as qualitative research in the screening model, the phenomenology pattern was used in the data collection and interpretation process. The study group consisted of 123 prospective teachers, 75 females and 48 males studying at Recep Tayyip Erdoğan University, Faculty of Education, Department of Turkish and Social Sciences Teaching, in the fall semester of the 2018-2019 academic year. Participants were asked to complete the prompt "Aesthetics is like ... because ..." to collect data. Both qualitative and quantitative procedures were utilized to analyze the data. Data analysis consists of determining metaphors (coding and extracting), classification of metaphors, developing categories, ensuring validity and reliability, and transferring data to the computer. The data were read and coded by two experts.

\section{Results}

In the study, 123 participants developed 69 metaphors differently for their "aesthetic" value. 48 of these metaphors were produced by only one participant. Metaphors produced by the participants regarding their aesthetic value are given in 7 categories: "Aesthetics as beauty (39)," Aesthetics as harmony "(21)," Aesthetics as an impressive asset "(18),"Aesthetics as a difference "(13), "Aesthetics as a source of happiness", (12),"Art Aesthetics (12), "Aesthetics as a reflection tool" (8). In this study, the same metaphor could be found in different 
categories. This is due to the participants' attribution of different meanings to same metaphor. This study shows that the vast majority of the participants perceive the aesthetic value as an object representing beauty, harmony in nature and life, and an impressive and joyous being. In the study where Kilcan and Akbaba (2014) determined the perceptions of the eighth-grade students at the lower, middle and upper socio-economic levels, they showed that the students had similar perceptions regarding the aesthetic value. Brisard (2002) states that metaphors as an object of meaning are influenced by the linguistic, cognitive, affective, and socio-cultural level of the person who expresses it.

In the "Aesthetics as a beauty representation" category, 39 participants stated 20 different metaphors. These metaphors are as follows: Beauty (7), nature (6), water (3), peacock (2), diamond (2), life (2), flower (2), operation (2), artificiality (2), body (1), ocean (1), pearl (1), created being (1), structure (1), perfection (1), universe (1), knowledge (1), painting (1), appearance (1), and art (1). Some participant statements in this category are given as below:

"Aesthetics is like body because it brings to the mind a person's appearance, outfit, and facial beauty" (M, 23)

"Aesthetics is like a peacock because at first glance something is incomprehensible, but it has hidden beauty." (F, 107)

In the "Aesthetics as harmony" category, 21 participants stated 17 different metaphors. These metaphors are nature (3), sun (2), sea (2), ivy (1), table (1), whole (1), ratio (1), golden ratio (1), mathematics (1), geometric shape (1) something modified (1), universe (1), human (1), sky (1), rainbow (1), sunrise (1), and moon piece (1). Some participant statements in this category are given below:

"Aesthetics is like golden ratio, because with a slight deviation everything will be out of balance". (M, 3)

"Aesthetics is like mathematics because everything is increasing and decreasing arithmetically in a certain direction in a certain way in nature.” $(\mathrm{M}, 46)$

The category of "aesthetics as an impressive asset" was defined by 18 participants with 13 different metaphors. These metaphors are universe (4), flower (2), emotion (2), sunset (1), ocean (1), newborn baby (1), mother (1), watching the sunset (1), woman (1), a beautiful girl (1), touch (1), benefit (1) and the world (1). Some participant statements in this category are given below:

"Aesthetics is like sunset because the image that emerges at sunset is fascinating and enchanting." (F, 91) 
"Aesthetics is like the universe because it is seen that the universe has a unique design." (F, 103).

Despite the abstract and complex meaning of the concept of aesthetics, the employment of metaphors that emphasizing the artistic and aesthetic features of nature shows that nature is not only perceived as a living space where our physical needs are met, but also a space that has artistic and aesthetic aspects.

The category of "aesthetics as a difference" was defined by 13 participants with 11 metaphors. These metaphors are eye (3), climate (1), structure (1), universe (1), season (1), food (1), table (1), variability (1), political view (1), lifestyle (1), and team keeping (1). Some participant statements are as follows:

"Aesthetics is like an eye because aesthetics is a subjective feeling." (F, 99)

"Aesthetics is like climate because there are four different seasons each year and aesthetics changes just like the climate." $(F, 102)$

In the "Aesthetics as a source of happiness" category, 12 participants stated 11 different metaphors. These metaphors are love (2), music (1), poetry (1), sun (1), fragrance (1), flower (1), Messi's football (1), wet in the rain (1), perfection (1), redbud (1), and art (1). Below are some expressions of participants in this category:

"Aesthetics is like music because when its rhythm is formed correctly, it is something that gives pleasure." $(\mathrm{F}, 83)$

"Aesthetics is like the sun because the presence of the sun pleases us and we enjoy it." (F, 71)

While the concept of aesthetics is explained with concepts such as balance, harmony, and life on the one hand, it is has been associated with artistic and natural beauty and concepts that give people pleasure, excitement and happiness on the other hand.

"Aesthetics as Art" category was defined by 12 participants with 7 different metaphors. These metaphors are art (4), painting (2), sculpture (2), building (1), historical building (1), Selimiye Mosque (1), and magic wand (1). Below are some expressions of participants in this category:

"Aesthetics is like art because it is an image that appeals to the subjective eye that comes from an artist." (M, 25)

"Aesthetics is like sculpture because shaping dough require a consideration down to the finest detail." (F, 77) 
8 participants stated 6 different metaphors in the category of "Aesthetics as a reflection tool". These metaphors are; table (2), mirror (2), imagination (1), daisy in the desert (1), yellow-red (1), and picture (1). Below are some expressions of participants in this category:

"Aesthetics is like a painting because people reflect what they see around them." (F, 19)

"Aesthetics is like a mirror because it makes our emotions visible and emotions speak." (F, 5)

In the research, male and female participants developed metaphors in all of the categories. In the "aesthetics as a reflective tool" category, male and female participants produced an equal number of metaphors. In other categories, female participants developed more metaphors. This may be due to the fact that women have a higher aesthetic perception than men and that women make more careful observations and attribute different meanings to objects or beings around them. As a matter of fact, Demirel (2018) states that females' views and awareness of the artistic and cultural beauties observed in their environment are more positive than males. Within the scope of the research findings, the following suggestions were developed:

- In terms of the number of metaphors developed, further studies can be conducted, especially on the causes behind female participants' higher scores

- The field literature can be developed with new studies in which the metaphors are determined at different grade levels related to the variable under consideration.

- Detailed studies on aesthetic value can be carried out using different data collection tools. 